\title{
Composites Produced from Natural Rubber and Chrome-Tanned Leather Wastes: Evaluation of their In Vitro Toxicological Effects for Application in Footwear and Textile Industries
}

\author{
Dalita G. S. M. Cavalcante ${ }^{1}$ Andressa S. Gomes ${ }^{1} \cdot$ Renivaldo J. Santos $^{1}$ \\ Leandra Ernst Kerche-Silva ${ }^{1}$. Caroline Silva Danna ${ }^{1}$ Eidi Yoshihara ${ }^{2}$. \\ Aldo E. Job ${ }^{1,3}$
}

Published online: 8 April 2017

(C) Springer Science+Business Media New York 2017

\begin{abstract}
A new composite has been developed from natural rubber and chrome-tanned leather waste for use in footwear and textile industries. The contribution of this material to environmental quality and sustained development should be highligh because chrome tanned leather wastes, a major environmental problem, can be recycled. However, the safety of this new material for human use is questionable, as it is already well reported in the literature that chromium, particularly in its hexavalent oxidation state, can be genotoxic and carcinogenic to living beings. Thus, the aim of this study was to evaluate in vitro biocompatibility of this composite material for possible use in the footwear and textile industries, through cytotoxicity, cell adhesion, and genotoxicity tests. Inductively coupled plasma optical emission spectrometry (ICP-OES) was used to measure both concentrations of total and hexavalent chromium. Based on the findings, it was concluded that the composite exhibits low levels of cytotoxicity and genotoxicity, and possesses favorable properties for initial cell adhesion. Furthermore, it was verified that the composites released low concentrations of chromium and that the predominant species released would be trivalent chromium. The results of the present study open the possibility of the incorporation of solid residues of tanned leather into chromium without
\end{abstract}

Aldo E. Job

job@fct.unesp.br

1 Department of Physics, Chemistry and Biology, Faculty of Science and Technology, UNESP, CP 467, Presidente Prudente, SP 19060-080, Brazil

2 São Paulo's Agency for Agribusiness Technology, APTA, Presidente Prudente, SP 19015-970, Brazil

3 Rua Cyro Bueno, 40. Bairro Morumbi, Presidente Prudente, SP 19060-560, Brazil necessarily the chromium contained in these residues influences the toxicity and genotoxicity of this new material.

Keywords Chromium $\cdot$ Natural rubber $\cdot$ Leather . Cytotoxicity $\cdot$ Genotoxicity $\cdot$ Cell line

\section{Introduction}

The leather manufacturing process generates a large amount of chrome-tanned leather solid wastes (LW), which are usually incinerated or discarded in landfills or inappropriate places. Inappropriate disposal may lead to contamination of the environment and consequently affect living organisms, including humans $[1,2]$. Various methods of treatment of these wastes have been described, and most of them have been designed to remove the chromium intercalated in collagen fibers [3]. Another possible alternative for reducing environmental impacts is the recycling of such waste. This alternative is interesting because it could transform waste into valuable resources through proper waste management [4]. Several studies have investigated different types of recycling to incorporate the $\mathrm{LW}$ into various materials, such as composites with potential applications in the textile and footwear industry [5-7]. The idea of recycling LW through its incorporation into new materials and products is suitable, as giving economic value to the waste also contributes to environmental quality and sustainable development and creates the possibility of reusing this waste, which is a major environmental problem.

Following this tendency, a composite material was developed from natural rubber (NR) and chrome-tanned leather wastes (LW) with possible applications in the footwear and textile industry, and prototypes of footwear that could be created with this new composite have been 
developed with the aim of testing the viability of the material (Fig. 1). This new material can be classified as a new market trend: eco-friendly product, that is, a product has contributed environmental impact reduction [8]. However, the question arises as to the safe use of this new material for human beings, since the LW used for the production of the composite contains chromium traces and may be in direct contact with human skin. It has already been well reported in the literature that chromium, particularly in a state of hexavalent oxidation, can be toxic, genotoxic, and carcinogenic to living beings [9]. Moreover, the presence of chrome in leather products has been associated with the onset of allergy and contact dermatitis [10].

The isolated toxicity of many substances, such as chromium, is already well known, but knowledge of the toxicity of these substances as part of a product that comprises various other substances is still very limited [11]. Typically, organizations such as the Oeko-Tex 100, which provides the highest textile certification system in Europe, evaluate the toxicity of products through chemical tests to quantify the permissible limits of dangerous substances in products for human beings [12]. Although the toxicological monitoring of materials based on the concentration of chemical components is extremely important, it is necessary to point out that people come into contact with a lot of materials that are made up of complex mixtures, not just individual

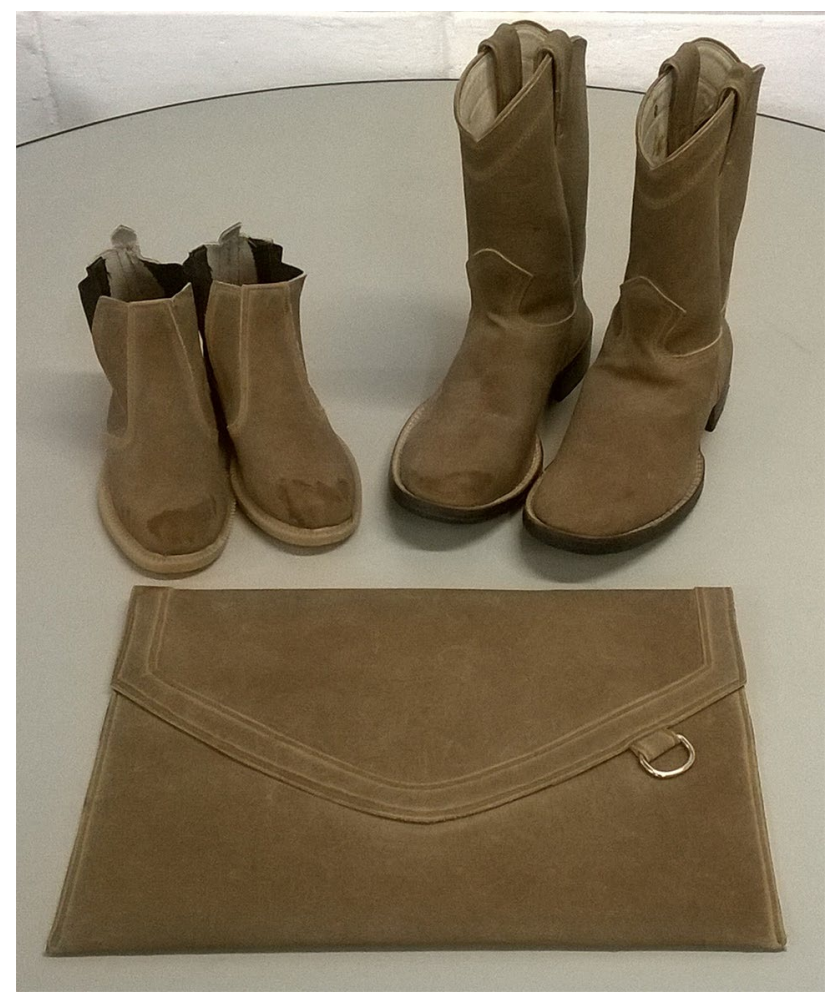

Fig. 1 Examples of products that can be made with the composite produced from natural rubber and chromium tanned leather waste substances. In these cases, cell-based assays could be important tools for evaluating the potential toxicity of the different combined substances [11]. Among in vitro biocompatibility tests, cytotoxicity tests are widely used and recommended by ISO 10993-5 for evaluating the potential toxicity of a material [13]. Genotoxicity tests in vitro are also supported by ISO 10993-3 for assessing damage to the genetic material of cells [14]. Another way to measure the biocompatibility of a material is the assessment of cell behavior on the material surface, such as cell adhesion [15].

Thus, since the proposed application of this new composite obtained from natural rubber and chrome tanned leather solid waste is to be incorporated into textile and footwear applications and because it may be in direct contact with human skin, the aim of this study was to evaluate the biocompatibility of this new composite. For this purpose, in vitro cytotoxicity, cell adhesion and genotoxicity tests were made to estimate the safety of this material and to assess the possible biological damage that this new material could cause in human beings.

\section{Experimental Section}

\section{The Studied Composite}

The studied composite was prepared based on Santos et al. [16]. This material comprises a mixture of Brazilian clear crepe NR and LW in the proportion of $100 \mathrm{~g}$ of NR to $20 \mathrm{~g}$ of LW. For NR vulcanization, activator reagents (stearic acid and zinc oxide), a curing agent (sulfur), and accelerator reagents (MBTS and TMTD) were used. A plasticizer (polyethylene glycol) and antioxidant (2,2,4-trimethyl1,2-dihydroquinoline polymerized) were also used. To produce materials with different colorings, iron oxide and titanium dioxide pigments were added, and a brownish (COF) and a whitish (CDT) material were obtained, respectively (Fig. 2). All reagents were mixed in a Banbury mixer chamber, and the vulcanization process was done by autoclave.

\section{Cell Line}

The cell line used in this study was CHO-K1 (Chinese hamster ovarian cells). Cells were cultured in $10 \mathrm{~mL}$ DMEM/F10 supplemented with $10 \%$ fetal bovine serum in cell culture flasks with a $25-\mathrm{cm}^{2}$ growth area maintained in an incubator with $5 \% \mathrm{CO}_{2}$ at $37^{\circ} \mathrm{C}$.

\section{Evaluation of the In Vitro Cytotoxicity}

Evaluations of the in vitro cytotoxic potential of COF and CDT composites were carried out using the extract dilution method and the direct contact method. For extract 
Fig. 2 Composite obtained from natural rubber and chrome tanned leather solid waste with different colorings: a Brownish (COF) and $\mathbf{b}$ whitish (CDT)

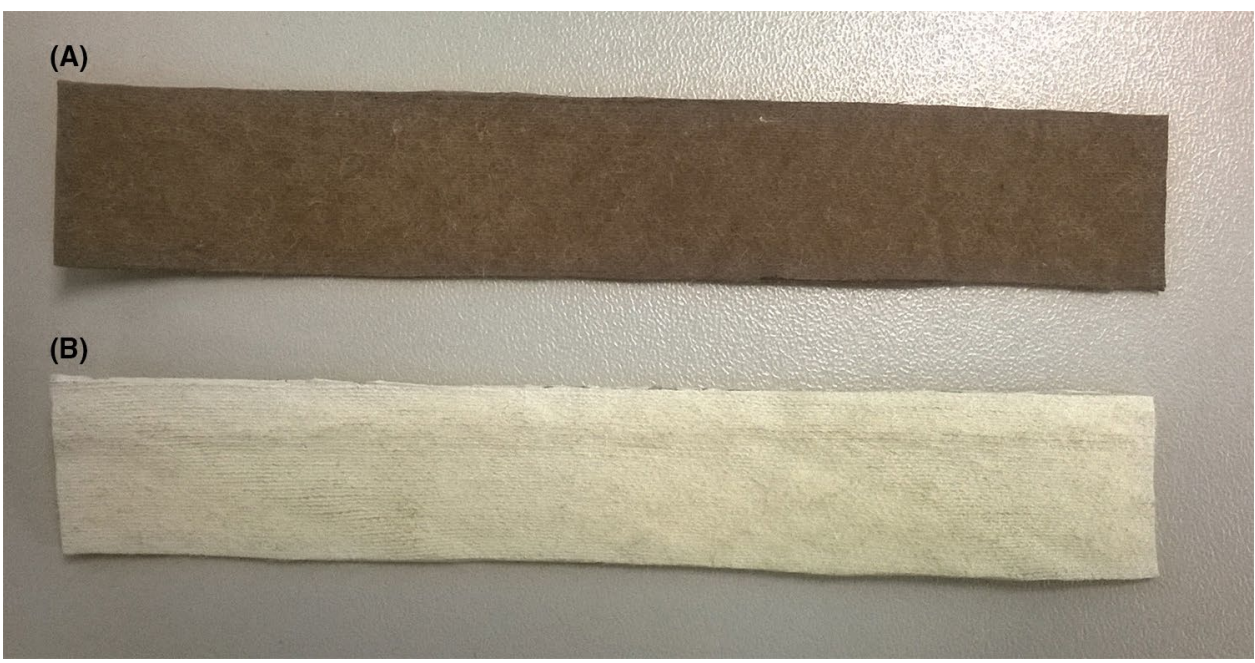

dilution method, liquid extracts of the composites (COF and CDT) were obtained following ASTM F619 standards [17]. The composite sample was crushed into pieces, mixed with an extraction solution (phosphate-buffered saline [PBS], $\mathrm{pH} 7.4)$ at a ratio of $60 \mathrm{~cm}^{2} / 20 \mathrm{~mL}$, and maintained under these conditions for $24 \mathrm{~h}$ without agitation. Thereafter, the solid pieces of composite material were removed, and the liquid extract was filtered, $\mathrm{pH}$ adjusted to 7.4 with $\mathrm{NaOH}$, and used to carry out biological assays. For the characterization of liquid extracts, ICP-OES was used to quantify the concentration of the total chromium and hexavalent chromium. The samples were subjected to acid digestion using concentrated nitric acid followed by ICP-OES quantification using an Optima 8000 ICP-OES spectrometer (PerkinElmer). After preparing the extracts, the cells were seeded in a 24 -well plate at a density of $1.0 \times 10^{5}$ cells per well. The cells were exposed to $100 \mu \mathrm{L}$ of extract of COF, CDF, or PBS as a negative control (NC) for 24-48 h. An equal amount of culture medium $(100 \mu \mathrm{L})$ was added to each well. After the exposure period, the cytotoxic potential of extracts was assessed using the MTT reduction method (Mosmann) [18]. For the MTT reduction method, $0.3 \mathrm{mg} /$ $\mathrm{mL}$ MTT solution was added and cells were incubated at $37^{\circ} \mathrm{C}$ for an additional $4 \mathrm{~h}$. Thereafter, the culture medium was removed, and dimethyl sulfoxide (DMSO) was added. The absorbance of each sample at $492 \mathrm{~nm}$ was determined using a microplate reader. The absorbance of the NC was considered to represent $100 \%$ cell viability $(\mathrm{CV})$. The $\mathrm{CV}$ of the other samples was determined using the following formula: $\mathrm{CVE}=[(\mathrm{AE}-\mathrm{AB}) /$ $(\mathrm{ANC}-\mathrm{AB})] \times 100$, where $\mathrm{CVE}=$ the cell viability of cells exposed to the extract, $\mathrm{AE}=$ the absorbance of cells exposed to the extract, $\mathrm{ANC}=$ the absorbance of cells exposed to $\mathrm{PBS}$ and $\mathrm{AB}=$ the absorbance of the blank (well containing a culture medium only).
For the direct contact method was used $100 \mathrm{~mm}^{2}$ square pieces of COF and CDT composites that were sterilized with ethylene oxide. The cell suspension was distributed in a six-well plate at $37^{\circ} \mathrm{C}$ for the formation of the cell monolayer. Then, fragments of the composite or nontoxic filter fragments (NC) were placed on the center of the well plate in contact with the cells for a period of $24-48 \mathrm{~h}$. After the exposure period, the cytotoxicity was evaluated by the crystal violet dye method. The cytotoxicity tests were based on macroscopic observations, which took into account the size of the formed halo, which was measured with a caliper rule. The degree of cytotoxicity of a material was based on the halo size, when no halo was detected, there was no cytotoxicity (grade 0 ). Additionally, a sample limited halo meant slight cytotoxicity (grade 1), a halo less than $0.5 \mathrm{~cm}$ meant mild cytotoxicity (grade 2), a halo between 0.5 and $1 \mathrm{~cm}$ meant moderate cytotoxicity, and a halo greater than $1 \mathrm{~cm}$ meant severe cytotoxicity (grade 3 ) $[13,19]$.

\section{Evaluation of Cell Adhesion}

To study the interaction of cells with the surface of the composite, cell adhesion tests were performed using two different methodologies. In the first method (an adhesion test quantified by MTT assay), composite fragments or glass coverslips (NC) were placed into a 48-well plate, covering the bottom of culture plate well. Then the cell suspension in culture medium was seeded on the materials and direct contact was established between the cells and the materials, lasting 24-48 h. After the exposure period, the culture medium was removed, and the wells were washed with PBS to remove non-adherent cells. Then, the adhesion of the cells was evaluated by MTT assay as previously described in the cytotoxicity test using the extract dilution method. To carry out the second method (an adhesion test quantified by scanning electron microscopy, or SEM), 
the exposure mode was similar to that described for the first cell adhesion assay methodology. After the exposure period, the samples were washed with PBS to remove nonadherent cells and fixed with a $2.5 \%$ glutaraldehyde for $1 \mathrm{~h}$. Then, the samples were dehydrated sequentially with ethanol $(30,50,70,90$, and $100 \%)$, dried at room temperature, coated with a thin layer of gold, and examined by scanning electron microscopy.

\section{Evaluation of DNA Damage}

For the evaluation of possible damage to the DNA of cells exposed to the COF and CDT composites the alkaline version of the comet assay was performed. For this, cells were seeded at a density of $1.0 \times 10^{5}$ cells in a 12 -well plate. Cells were exposed to the same liquid extracts $(1 \mathrm{~mL})$ previously described or PBS (NC) for a period of 24 and $48 \mathrm{~h}$. An equal amount of culture medium $(1 \mathrm{~mL})$ was added to each well. After the exposure period, the adherent cells were trypsinized, and fetal bovine serum was added. The resulting cell suspension was used to prepare slides for the comet assay as described by Singh et al., with slight modifications [20]. The samples were mixed with lowmelting-point agarose $(0.5 \%)$ and divided into two glass slides that had been previously coated with a layer of normal-melting-point agarose (1.5\%), covered with coverslips, and incubated for $30 \mathrm{~min}$ at $4{ }^{\circ} \mathrm{C}$ to solidify the agarose. Thereafter, the slides were placed in a lysis solution $(2.5 \mathrm{M}$ $\mathrm{NaCl}, 100 \mathrm{mM}$ EDTA, $10 \mathrm{mM}$ Tris, $1 \%$ Triton X-100, and $10 \%$ DMSO) for $1 \mathrm{~h}$. After the lysis step, all slides were transferred to an electrophoresis tank containing a freshly prepared cold alkaline buffer ( $1 \mathrm{mM}$ EDTA and $300 \mathrm{mM}$ $\mathrm{NaOH}, \mathrm{pH}>13$ ). The slides were incubated for $30 \mathrm{~min}$ to unwind DNA, and electrophoresis was performed at $25 \mathrm{~V}$ and $300 \mathrm{~mA}$ for $20 \mathrm{~min}$. Thereafter, they were placed in a neutralizing solution ( $0.4 \mathrm{M}$ Tris, $\mathrm{pH} 7.5)$ and fixed with absolute ethanol. The slides were then stained with DAPI solution $\left(1 \mathrm{mg} / \mathrm{mL}\right.$ DAPI $\left.\mathrm{H}_{2} \mathrm{O}\right)$ and visualized by fluorescence microscopy. One hundred cells were counted per slide, and DNA damage was classified into four categories according to the migration of DNA fragments, as described by Kobayashi et al. [21].

\section{Statistical Analysis}

The results were compared by parametric analysis of variance (ANOVA) using the Student-Newman-Keuls method or the non-parametric Kruskal-Wallis test, in accordance with the distribution of the data (normality and homogeneity of variance). $p<0.05$ was considered significant, and the results were expressed as means $\pm \mathrm{SD}$.

\section{Results and Discussion}

The majority of chromium found in leather waste is in the trivalent oxidation state and bound to collagen fibers. However, the presence of free chromium traces cannot be ruled out [22]. It is known that the greatest danger to human health does not arise from the presence of metals in textile products, but from the metals which can be extracted from the product by transpiration and later become more available to the cells $[23,24]$. According to Oeko-Tex standards, the most important certification system for textile products in Europe, the maximum chromium levels allowed in textile products is dependent on the product type. For children's products, the permitted maximum extractable limit is $1 \mathrm{mg}$ of total chromium per $\mathrm{kg}$ of product. For products with or without direct skin contact, the permitted maximum extractable limit is $2 \mathrm{mg}$ of chromium per $\mathrm{kg}$ of product. Furthermore, hexavalent chromium should not be present in the final textile product [12]. In contrast, the international standards organization (ISO 17075:2007) permits a maximum extractable level of 3 ppm hexavalent chromium [13]. From the ICP-OES results obtained in this study, it was possible to ascertain that the amount of released total chromium was low; furthermore, if hexavalent chromium was present in both extracts, the concentration was below the detection limit of the measurement equipment, which was $50 \mu \mathrm{g} / \mathrm{L}$ (Table 1). Thus, it was possible to infer that the majority of the total chromium present in the extracts was in the trivalent oxidation state. Hedberg et al. [25] also observed that for $\mathrm{Cr}$ (VI) extracts obtained from leather, the concentration was below the detection limit of the equipment and $\mathrm{Cr}$ (III) was by far the predominantly released species in synthetic sweat. When comparing the concentrations of the total chromium and released hexavalent chromium from both composites with international standards, such as Oeko-Tex and EN ISO TS 17075, the concentrations of chromium released from both composites should not exceeded the permitted values $[12,26]$.

Table 1 Quantification of the concentration of total chromium and hexavalent chromium found in the extracts $(\mathrm{mg} / \mathrm{L})$ using ICP-OES $(\mathrm{N}=3)$ and their respective values in the unit $\mathrm{mg} / \mathrm{kg}$ composite

\begin{tabular}{|c|c|c|c|}
\hline & \multicolumn{2}{|l|}{$\mathrm{mg} / \mathrm{L}$ extract } & \multirow{2}{*}{$\begin{array}{l}\mathrm{mg} / \mathrm{Kg} \text { composite } \\
\text { Total chromium }\end{array}$} \\
\hline & $\begin{array}{l}\text { Total } \\
\text { chromium }^{\text {a }}\end{array}$ & $\begin{array}{l}\text { Hexavalente } \\
\text { chromium }^{\mathrm{b}}\end{array}$ & \\
\hline $\mathrm{COF}$ & $0.064 \pm 0.007$ & $<0.050$ & $0.19 \pm 0.02$ \\
\hline CDT & $0.065 \pm 0.02$ & $<0.050$ & $0.16 \pm 0.03$ \\
\hline
\end{tabular}

Detection limit

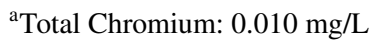

${ }^{\mathrm{b}}$ Hexavalente Chromium: $0.050 \mathrm{mg} / \mathrm{L}$ 
The low amount of total chromium released from the composites into the extraction media may be related to the fact that natural rubber is used as a template in the production of composite covers for leather fibers, which prevents solubilization of the available chromium [16]. It is important to note that the samples of the composites used for the preparation of the extraction media were freshly prepared; it is known that parameters relevant to occupational exposure, such as repeated exposure, wear, alkaline solutions, sequential wet and dry exposures, and aging, may influence the amount of total chromium released from the materials [27].

In the present study, the results obtained from the MTT assay using the extract dilution method showed that the extracts obtained from the COF and CDT composites did not affect the viability of CHO-K1 cells in any of the experimental tests (Fig. 3). The results of the direct contact test indicated the extensions of the halo formed between the material and the cells were significantly higher for both COF and CDT compared with the NC in both experimental periods (Fig. 4). Classification of the halo size formed indicated that both tested composites have a reactivity degree of two: they produce slight toxicity in cells directly exposed to the material. In order for a material to be considered a cytotoxic agent, it must have a cytotoxicity degree higher than two, i.e., the material induces the formation of a halo greater than $0.5 \mathrm{~cm}[13,19]$. We must consider that both composites studied are formed from not only chromium, but a variety of chemical substances, such as the reagents used for vulcanization and pigments (iron oxide and titanium dioxide), which could also be toxic to cells if released. Therefore, in vitro toxicity tests have proven to be an extremely valuable tool, as it is possible to obtain information about the toxicity of the product as a whole [11].These tests are even more valuable for products composed of materials with unknown chemical
Fig. 3 Cell Viability (\%) of CHO-K1 exposed to different extracts (COF or CDT) or only the culture medium (NC) for 24 and $48 \mathrm{~h}$, quantified the MTT assay. The horizontal lines represent the mean and vertical lines represent standard deviation

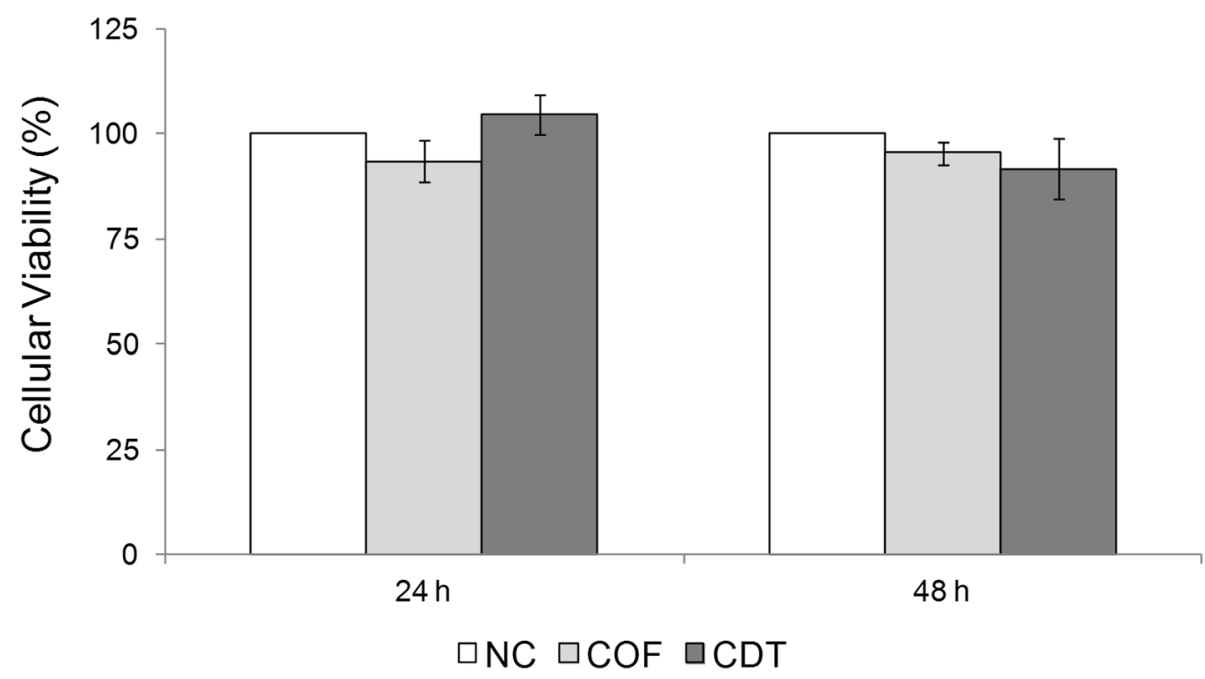

Fig. 4 Halo extension formed between $\mathrm{CHO}-\mathrm{k} 1$ cells and fragments (COF or CDT) after exposure of 24 and $48 \mathrm{~h}$. The horizontal lines represent the mean and vertical lines represent standard deviation. Asterisk Indicates significant difference compared to the respective negative control (NC) $(\mathrm{p} \leq 0.05)$

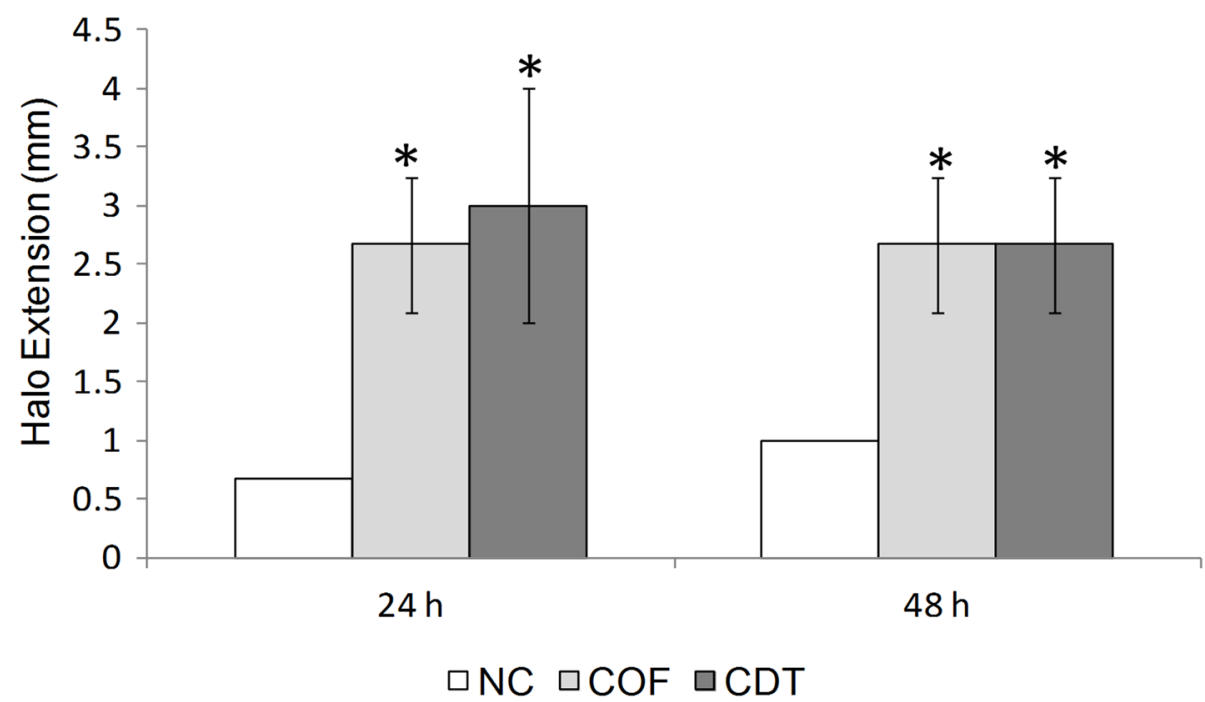


residues, as they allow for the assessment of the general toxicity of the material. This study focused only on chromium and we determined that chromium metal was released from the composites predominantly in the trivalent form, but the concentrations released were not sufficient to cause a significant change in the viability of the exposed cells. Generally, hexavalent chromium is much more toxic than trivalent chromium to biological systems, owing to the low ability of the $\mathrm{Cr}$ (III) ion ability to penetrate cell membranes. However, studies have shown that the toxicity of trivalent chromium is dependent on certain conditions, such as high concentration, long exposure times, and the type of connecting ligands, which may facilitate the entry of trivalent chromium into cells [28]. In the present study, the absence of cytotoxicity at the concentrations of chromium extracted from both composites $(64$ and $65 \mu \mathrm{g} / \mathrm{L}$ ) may be related to the concentration of trivalent chromium released, as well as the short exposure time tested (24 and $48 \mathrm{~h}$ ). Other similar studies have also found no influence on the viability of cells exposed to trivalent chromium at similar or higher doses than those used in the present study $[29,30]$. Current research by Novotnik et al. [31] indicated that concentrations of $40-25,000 \mu \mathrm{g} / \mathrm{L}$ trivalent chromium and $40-200 \mu \mathrm{g} / \mathrm{L}$ hexavalent chromium were not cytotoxic to the HepG2 cell line after a 24-h exposure period. Therefore, based on our results, we inferred that both composites showed no cytotoxic effects on the cell line tested.

In addition to the cytotoxicity assays, we assessed the adhesion behavior of CHO-K1 cells to the surface of the COF and CDT composites. The MTT-quantified adhesion test reports the number of cells that adheres to the composite and remains viable. The SEM-quantified adhesion test offers insight into the location and morphology of adherent cells [32].The results of the MTT-quantified adhesion test quantified showed a significant decrease in the number of viable cells that were exposed directly to the COF and
CDT composites compared with the NC in both experimental periods (Fig. 5). This indicated that the surface initially found by the cells did not favor adherence. The interaction between cells and artificial materials is governed by the physical and chemical properties of the surface of the material [33]. One such property, which may highly influence the adhesion behavior, is material topography [34]. It is known that surface roughness of a material can influence cell adherence, morphology, and proliferation [35]. Observation of the surface of both composites under SEM showed that it was possible to verify that both the COF and CDT composites featured surfaces with grooves, small protrusions, and recesses (Fig. 6c, e). These features can be classified on an irregularity scale for materials with surfaces exhibiting microroughness [36]. From the classification, we inferred that the irregularities present in both composites hindered the attachment of cells on the material. Deng et al. showed that the presence of surface roughness was an essential prerequisite to cell adhesion. However, up to a certain degree, higher levels of roughness may not favor cell adhesion [37]. SEM analysis also showed that adherent cells were preferably located in regions exhibiting protrusions and indentations, which indicated that the material possessed certain regions with more favorable adhesion properties than others (Fig. 6d, f).

As described in the present work, Rea et al. [38] also evaluated a composite and identified higher cell attachment to the protrusions and grooves on the surface of the material. In addition to the adhesion to the specific regions of the material, it was possible to observe, by using SEM, that cells attached to the surface of both composites had a rounded morphology (Fig. 6d, f), while cells attached to glass slides were stretched after a 48-h exposure period (Fig. 6a, b). Lee et al. [39] also observed cells with spherical morphology on the surfaces of membranes with increased roughness after 2 days. From these results,
Fig. 5 Cell viability of cells attached on glass slide or fragments (COF or CDT), quantified by the MTT assay. The horizontal lines represent the mean and vertical lines represent standard deviation. Asterisk Indicates significant difference compared to the respective negative control (NC) $(\mathrm{p} \leq 0.05)$

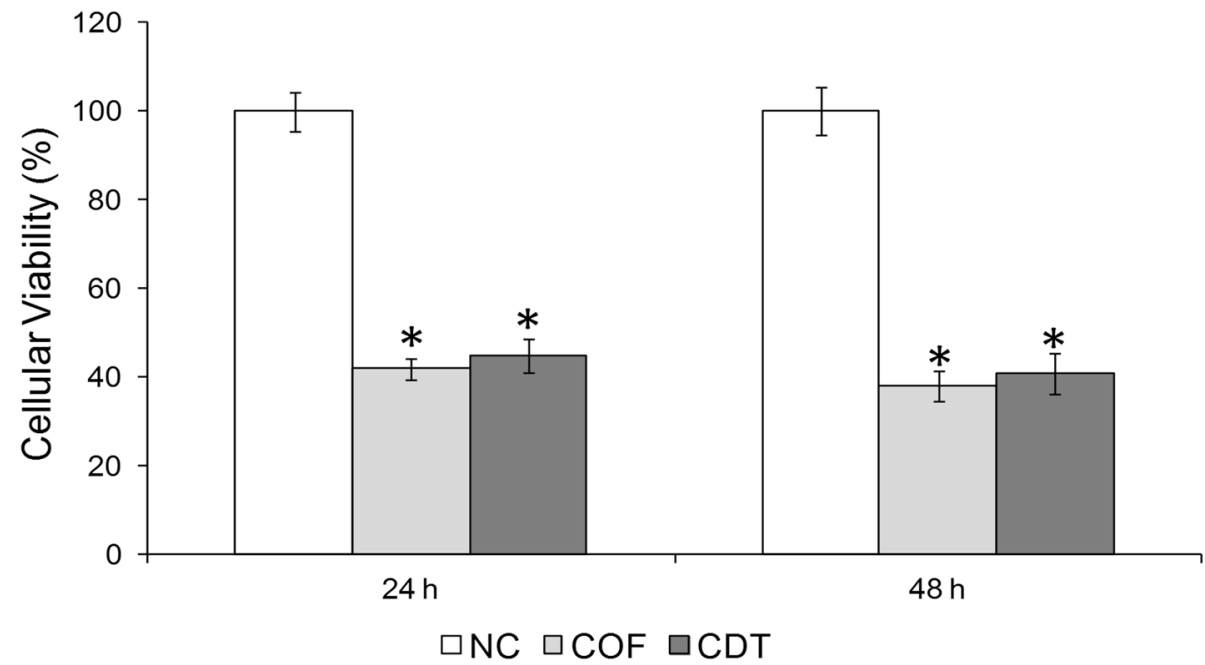



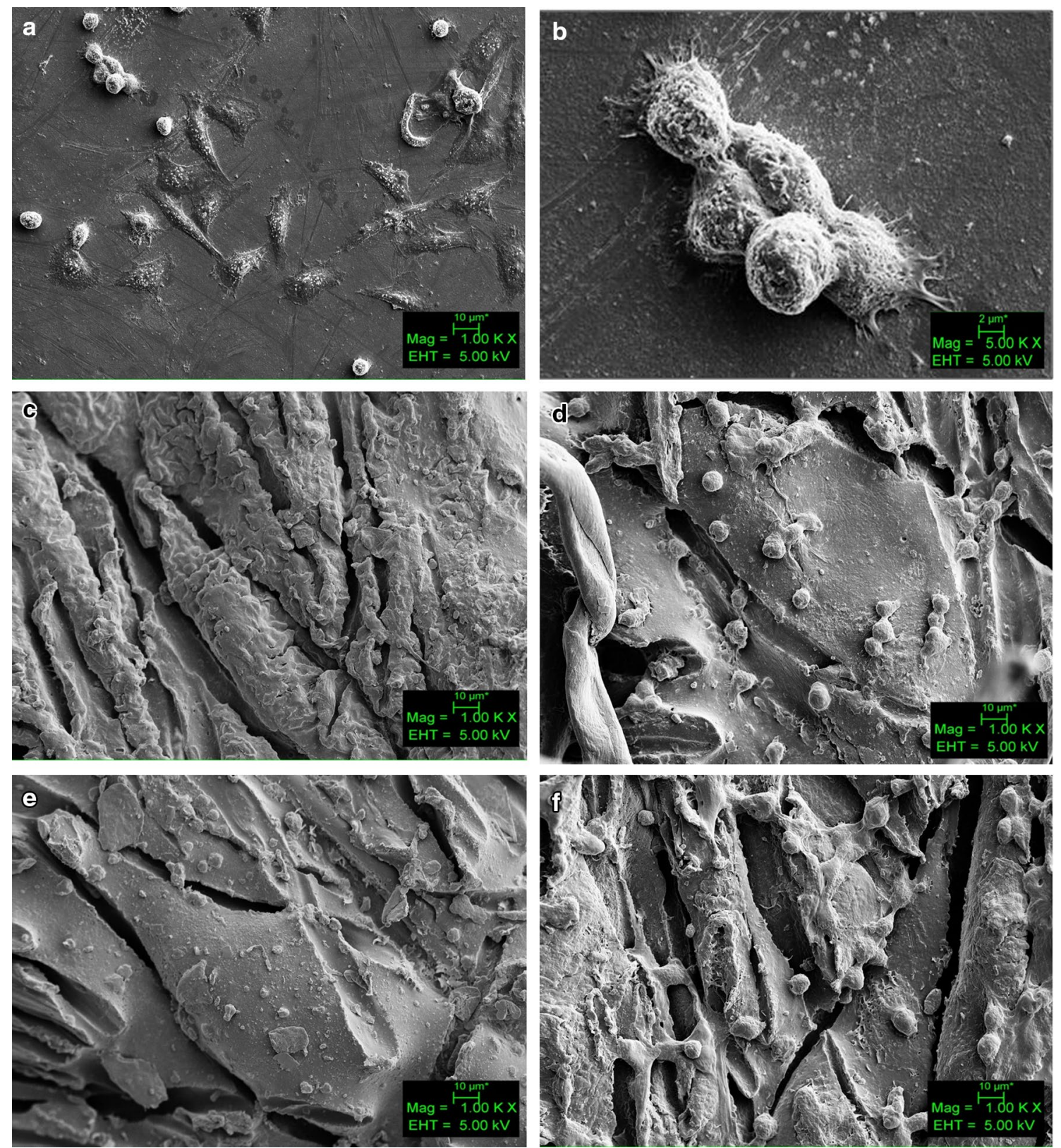

Fig. 6 SEM images of adherent cells: $\mathbf{a}$ and $\mathbf{b}$ glass coverslips; $\mathbf{d}$ COF fragment; $\mathbf{f}$ CDT fragment; $\mathbf{c}$ and $\mathbf{e}$ surface morphologies obtained for COF fragment and CDT fragment, respectively

we therefore inferred that the surfaces of both composites have regions with favorable properties for cell initial adhesion, but more studies are needed to evaluate the behavior of these cells over longer exposure periods.

A comet assay was performed to examine if the composites in the study could damage the DNA of exposed cells. The comet assay is a widely-used tool to assess DNA damage in different systems, particularly in human cells [40-42]. Several studies have already used the comet assay to assess the genotoxicity of various types of composites [43-45]. In the scientific literature, this is the second study that assesses the genotoxicity of composites containing chrome-tanned leather wastes; the first study was performed by our research group (Cavalcante et al.) [46], where it was determined that the cytotoxic and genotoxic effects were related to the reagents used during the vulcanization process and not to the presence of chromium. In the present study, the comet assay did not show significant differences in the levels of DNA damage in the cells exposed to COF and CDT extracts compared with the NC in either of the experimental periods (Fig. 7). These results reinforced the inference that the majority of the total chromium present in 
Fig. 7 DNA damage scores in CHO-K1 cells exposed to different extracts (COF or CDT) or only the culture medium (NC) for 24 and $48 \mathrm{~h}$, quantified by Comet assay

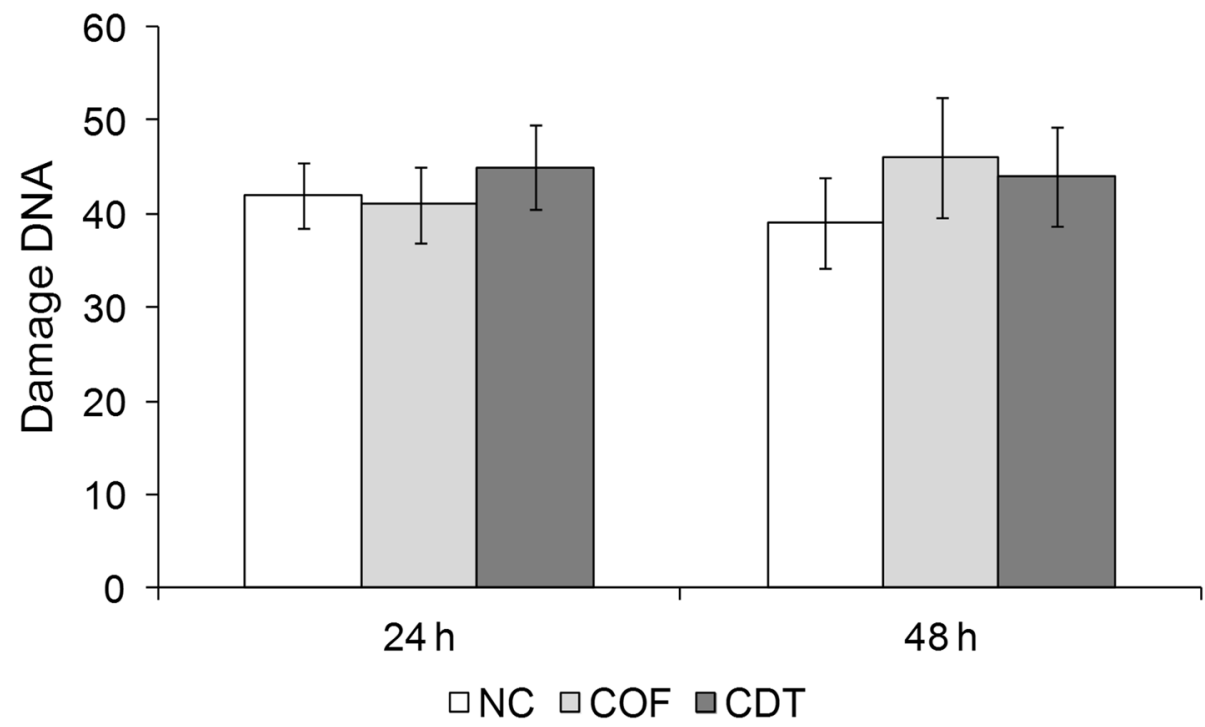

the extracts was in the trivalent oxidation state. Hexavalent chromium is well-known for its genotoxic and carcinogenic effects in human cells [47]. It has been reported that trivalent chromium, at high concentrations, can damages DNA molecules, sister-chromatid exchange, and the appearance of the micronucleus [48]. Consequently, we inferred that the absence of in vitro genotoxic effects found in this study resulted from the low concentrations of trivalent chromium available to cross the cellular membrane and interact with DNA molecules.

\section{Conclusion}

Our findings indicated that the composites obtained from chrome tanned leather wastes showed low cytotoxicity and genotoxicity for the evaluated in vitro test system. In addition, we deduced that the surface of both composites possessed regions with variability in the favorable properties for initial cellular adhesion. Furthermore, it was verified that the composites released low concentrations of chromium and that the predominant species released would be trivalent chromium. The initial screening of the in vitro toxicity and genotoxicity of these new composites suggested that the new materials can be used in the next generation of products in the textile and footwear industries. The results of the present study presented the possibility of the incorporation of solid residues of tanned leather into chromium without the chromium contained in these residues necessarily influencing the toxicity and genotoxicity of this new material. Consequently, we highlight the potential contribution of this research to the improvement of environmental quality and sustainable development, as it is has demonstrated the possibility of recycling solid waste from leather tanned in chromium, which is a major environmental problem. Finally, it should be noted that the in vitro cell assays proved to be an important tool for the evaluation of the cytotoxicity and genotoxicity of products intended for the consumer market.

Acknowledgements The authors acknowledge Fundação de Amparo à Pesquisa do Estado de São Paulo (FAPESP), for the financial support, and Agência Paulista de Tecnologia dos Agronegócios (APTA) for the use of its facilities.

Compliance with Ethical Standards

Conflict of interest The authors declare that they have no conflict of interest.

\section{Glossary}

MBTS 2,2'-dithiobis (benzothiazole)

TMTD Tetramethyl thiuram disulfide

ICP-OES Inductively coupled plasma optical emission spectrometry

MTT 3-(4, 5-dimethylthiazol-2-yl)-2, 5-diphenyltetrazolium Bromide

EDTA Ethylenediamine tetraacetic acid

DAPI 4',6-diamidino-2-phenylindole

\section{References}

1. Garcia NG, Reis EAP, Budemberg ER, Agostini DL da S, Salmazo LO, Cabrera FC, Job AE (2015) J Appl Polym 132:41636

2. Dixit S, Yadav A, Mukul PDD (2015) J Clean Prod 87:39

3. Jiang H, Liu J, Han W (2016) Waste Manage Res 34:399

4. U.S. EPA (2015) Advancing sustainable materials management: facts and figures. 2013. U.S. EPA, Washington, DC 
5. Ferreira MJ, Almeida MF, Freitas F (2011) Polym Eng Sci $51: 1418$

6. Senthil R, Hemalatha T, Kumar BS, Uma TS, Das BN, Sastry TP (2015) Clean Technol Environ Policy 17:187

7. Joseph S, Ambone TS, Salvekar AV, Jaisankar SN, Saravanan P, Deenadayalan E (2015) Polym Compos. doi:10.1002/pc.23891

8. Katsikeas CS, Leonidou CN, Zeriti A (2016) J Acad Mark Sci. doi:10.1007/s11747-015-0470-5

9. Mishra S, Bharagava RN (2016) J Environ Sci Health C Environ Carcinog Ecotoxicol 34:1

10. Hedberg YS, Lidén C (2016) Contact Derm 75:82

11. Klemola K, Pearson J, Liesivuori J, Lindström-Seppä P (2009) J TEXT I 100

12. Oeko-Tex (2016)https://www.oeko-tex.com100 [06 june 2016]

13. ISO 10993-5 (2009) Biological evaluation of medical devicesPart 5: tests for in vitro cytotoxicity. International Organization for Standardization, Geneva

14. Boutrand J (2012) Biocompatibility and performance of medical devices, 1st edn. Woodhead Publishing, Oxford

15. Anselme K (2000) Biomaterials 21:667

16. Santos RJ, Agostini DLS, Cabrera FC, Budemberg ER, Job AE (2015) Polym Compos 36:2275

17. ASTM F619 (2014) Standard practice for extraction of medical plastics. ASTM International, West Conshohocken

18. Mosmann T (1983) J Immunol Methods 65:55

19. ASTM F813-07 (2012) Standard practice for direct contact cell culture evaluation of materials for medical devices. ASTM International, West Conshohocken

20. Singh NP, McCoy MT, Tice RR, Schneider EL (1988) Exp Cell Res 175:184

21. Kobayashi H, Suguyama C, Morikawa Y, Hayashi M, Sofuni T (1995) MMS Commun 3:103

22. Cabeza LF, Taylor MM, Di Maio GL, Brown EM, Marmer WN, Carrió R, Celma PJ, Cot J (1998) Waste Manage 18:211

23. Rezić I, Steffan I (2007) Microchem J 85:46

24. Rizzi M, Cravello B, Ren F (2014) Cell Prolif 47:578

25. Hedberg YS, Lidén C, Odnevall Wallinder I (2015) Contact Dermat 72(4):206-215

26. DIN EN ISO 17075 (2007) Leather - Chemical tests-determination of chromium (VI) content. Technical Committee CEN/TC 289

27. Mathiason F, Lidén C, Hedberg YS (2015) Contact Dermat 72(5):275-285

28. Bagchi D, Stohs SJ, Downs BW, Bagchi M, Preuss HG (2002) Toxicology 180:5-22
29. Shrivastava HY, Ravikumar T, Shanmugasundaram N, M B, Balachandran UN (2005) Free Radic Biol Med 38:58-69

30. Hininger I, Benaraba R, Osman M, Faure H, Roussel AM, Anderson RA (2007) Free Radic Biol Med 42:1759-1765

31. Novotnik B, Scancar J, Mila R, Filipi M, Zegura B (2016) Chemosphere 154:124-131

32. Zangi S, Hejazi I, Seyfi J, Hejazi E, Khonakdar HA, Davachi SM (2016) Mater Sci Eng C 63:609

33. Bacakova L, Filova E, Parizek M, Ruml T, Svorcik V (2011) Biotechnol Adv 29:739

34. Assender H, Bliznyuk V, Porfyrakis K (2002) Science 297:973

35. Chang H-I, Wang Y (2011) Cell responses to surface and architecture of tissue engineering scaffolds. In: Eberli D (ed) Regenerative medicine and tissue engineering-Cells and biomaterials. InTech. https://www.intechopen.com/books/regenerative-medicine-and-tissue-engineering-cells-and-biomaterials

36. Vagaská B, Bacáková L, Filová E, Balík K (2010) Physiol Res 59:309

37. Deng Y, Liu X, Xu A, Wang L, Luo Z, Zheng Y, Deng F, Wei J, Tang Z, Wei S (2015) Int J Nanomed 10:1425

38. Rea SM, Brooks RA, Schneider A, Best SM, Bonfield W (2004) J Biomed Mater Res B Appl Biomater 70:250

39. Lee SJ, Choi JS, Park KS, Khang G, Lee YM, Lee HB (2004) Biomaterials 25:4699

40. Dhawan A, Bajpayee M (2009) Cell Biol Toxicol 25:5

41. Anderson D, Dhawan A, Laubenthal J (2013) Methods Mol Biol 1044:347

42. Collins AR (2015) Mutagenesis 30:1

43. Urcan E, Scherthan H, Styllou M, Haertel U, Hickel R, Reichl FX (2010) Biomaterials 31:2010

44. Shehata M, Durner J, Eldenez A, Van Landuyt K, Styllou P, Rothmund L, Hickel R, Scherthan H, Geurtsen W, Kaina B, Carell T, Reichl FX (2013) Dent Mater 29:971

45. Styllou M, Reichl FX, Styllou P, Urcan E, Rothmund L, Hickel R, Högg C, Scherthan H (2015) Dent Mater 31: 1335

46. Cavalcante DGSM, Gomes AS, Reis EAP, Danna CS, Kerche - Silva LE, Yoshihara E, Job AE (2016) TToxicol Ind Health. doi:10.1177/0748233716674398

47. Wise SS, Holmes AL, Liou L, Adam RM, Wise SJP (2016) Toxicol Appl Pharmacol 296:54

48. Figgitt M, Newson R, Leslie IJ, Fisher J, Ingham E, Case CP (2010) Mutat Res 688:53-61 